\title{
Breaking food safety and quality standards in the EU: Financial aspects within poultry products manufacturers in Visegrad 4 countries
}

\author{
Andrea Komínková \\ Department of Business Economics, Mendel University in Brno, \\ Brno, Czech Republic \\ xkomink3@node.mendelu.cz.
}

\author{
Jan Vavřina \\ Corresponding author \\ Department of Business Economics, Mendel University in Brno, \\ Brmo, Crech Republic \\ jan.vavrina@mendelu.cr. \\ Josef Polák \\ Department of Economics and Management, \\ The College of Regional Development and Banking Institute - \\ AMBIS, \\ Prague, Crech Republic \\ josef.polak@ambis.cr.
}

Abstract. Under changing consumer preferences towards the need to increase qualitative side of food consumption,the level of meeting EU food safety and quality standards can be discussed as a specific factor of competitiveness for food manufacturers. The EU member countries use an information exchange instrument named Rapid Alert System for Food and Feed (RASSF) for sharing information with both public authorities and consumers. An increasing number of food safety and quality problems was observed in the year 2019 regarding the industry branch EU NACE 1012 - poultry meat and poultry meat products in CEEC countries. This paper aims at the identification of common factors in the financial performance of businesses active in the industry mentioned above within Visegrad 4 member countries focusing on a specific distinctive period between 2009 and 2017. The authors employ factorial analysis of variance approach together with a post hoc Scheffé test for revealing similarities/dissimilarities within the selected key financial performance indicators for the sample of poultry meat and poultry meat products manufacturers. Namely, factors to be researched are country of business entities' settlement, economic size and time proxy variable element of the

Received:

1st Revision:

February, 2020

Accepted:

June, 2020

DOI: $8330.2020 / 13-3 / 13$ 
observed years. The sample consists of different size categories of manufacturers, which were active in the Visegrad 4 countries during the period from 2009 to 2017, to cover both the period of economic downturn and the period of economic growth renewal. The source of harmonized secondary corporate financial data was the database ORBIS of Bureau Van Dijk. The presented results support the need for the existence of the EU food safety and quality policy on both consumers' side and the side of producers to create and sustain equal and fair competitive environment in this industry. The conducted empirical analysis on financial microbusiness data of poultry meat and poultry meat products manufacturers in V4 countries proved a prevailing cost efficiency and productivity focus before safety and quality of production (measured by the number of the reported incidents in EU RASFF). The authors claim that accessible microfinance data on food manufacturers and their respective branches could help enhance the processes of effects' identification for safety and quality food governance, not only at the EU level but also at the level of respective EU member countries' authorities.

Keywords: business performance, competitiveness, consumer behavior, costeffectiveness, financial management, food processing industry, food quality regulation.

JEL Classification: Q18, D22, C55

\section{INTRODUCTION}

The issue of food quality is a long-term problem intertwined with several scientific disciplines. This is associated, for example, with the topics of population nutrition, general awareness of food contents, developing standards and amending legislation, consumer behaviour and preferences, food incidents, factors affecting the composition and quality of food and many other topics. In the context of performance and competitiveness, it is also necessary to perceive the performance issues of businesses operating in the food manufacturing industry, which is under pressure of cost optimization like other sectors, as it is also facing international market environment and regulations. Food producers settled in Visegrad 4 member countries had to adapt to the EU quality and safety regulations at the date of the entrance or after ending of the transition period. Adopted by businesses entities changes for meeting the EU standards in the whole food production industry were bind with capital investments. The need for an acceptable return on that investments is however limited by the situation on the market, specifically by the purchasing power of retail chains. This situation often forces food producers to cost savings, which affect all the factors of production, including quality.

Food production quality management in the EU member countries is an important part of the EU policies and it is interconnected with food security issues. At the level of individual enterprises food quality can be joint with other goals of business activities, i.e., within the system of planning financial and non-financial indicators (Michalski, 2016). The aforementioned financial indicators can be then considered as partial evidence for the identification of quality-influencing factors. This mutual relation is identified e.g. by Thomas (2019) who described the impacts of food regulation on the business operational cost side or Gómez et al. (2019) who was pointing out changes in agri-food business and respective financial consequences. 
The objective of this article is to identify common factors in the financial performance of businesses active in the industry poultry meat and poultry meat products in the Visegrad 4 member countries that represent food manufacturing with an increasing number of cases of breaking food safety and quality rules. Unlike some other studies on the same topic, this article focuses on the microfinancial data of the manufacturers settled in the Visegrad 4 within a specific industry EU NACE 1012 - manufacturing of poultry meat and poultry meat products. Back in 2019, this industry had one of the highest numbers of food safety and quality alerts. The research gap for this work to fill was found in the course of the survey, and conclusions were drawn on a combination of essential factors from both businesses' and consumers' sides, specifically on the companies' performance in an environment burdened by the growing degree of regulation in part of food quality. Studies and works of other authors mentioned in the next chapter focus mainly on the performance of companies, consumer behaviour, legislation or consumer literacy concerning food quality.

The structure of the empirical part of this article is as follows. It is subdivided into three main sections according to the defined hypothesis on the existence of common factors within selected dependent variables, represented by respective financial indicators. Namely, these financial indicators are Total Assets Turnover, Profit Margin and Cost Efficiency of Employees. Partial results are discussed in comparison with the findings of other authors. Further information on the employed materials and methods is provided in chapter 3 .

\section{LITERATURE REVIEW}

The food processing industry in the context of food safety and security standards has to be considered as a mutually interconnected system with a broader scope of relations. Every part of this system, i. e. farmers, distributors, processors or merchandisers are responsible for the quality constitution processes (e.g. Matošková and Gálik, 2009; Anderson, Asche and Garlock, 2019). Agri-food chains face a broad range of incorporated requirements for food quality, but in fact from the business point of view customers are the most important assessors of quality of production (e.g. Hron and Macák, 2010; Morano et al., 2018). Innovation activities in the food processing industry can provide a positive influence to meet changing requirements for food safety and quality among producers settled in EU member countries (Cepel, Belas, Rozsa, \& Strnad, 2019; Long, Looijen, \& Blok, 2018; Ministry of Agriculture of the Czech Republic, 2018).

A general characteristic of the food processing industry in CEES countries is lagging behind economic performance in comparison with EU core countries. The reason for this situation can be found in the fact that prevailing amount of production, which is processed and placed on the market, is assessed as providing a lower utility value by the consumers' side. Dudek (2019) examined food insecurity in the EU, specifically in the V4. The author perceives food insecurity as a situation when people affected by this problem cannot afford enough food of sufficient quality and quantity that would allow them to stay healthy and participate in society. The results of her research show that households' food insecurity is connected with income, level of urbanization, household type, disabilities of household members, and attributes of the household head like educational attainment, gender, age, health and status of economic activity. From this, it is clear that this phenomenon will be different in each region of the V4 countries, but they are compact economies in the global perspective. The results of her research also confirmed that food insecurity is represented in vulnerable households in the Visegrad Group countries. As a result, we assume that we work with an environment in our research that provides data that can be viewed from the same perspective. Similarly, Erokhin (2017)provides findings of lower quality products placed on the market by domestic producers in Russia, when it is compared with exported goods. Insufficient 
purchasing power in satisfying consumer demand for food is not according to e.g. Palát (2014) problem of third world countries only.

Volek, Novotná, \& Zeman (2019) discussed in their article the issue of labour productivity and the competitiveness of SMEs in the food industry. The authors examined the link between these two factors on a sample of 160 Czech SMEs companies in the food industry. They expressed competitiveness using selected financial indicators such as Return on Assets, Return on Sales, Current Liquidity, Altman - ZETA model, model IN05. Mutual relationships of variables were examined through correlation and regression analysis. They found that the link between labour productivity and competitiveness depends heavily on defining indicators for competitiveness, while the strongest correlation was found between labour productivity and competitiveness expressed by an indicator of return on sales. They identified ROA and ROS as suitable indicators. The rapid rise in wages in the food industry has been identified as a factor affecting labour productivity, which may result in a decline in competitiveness. However, profitability is also affected by the management of working capital, as Vukovic, Andric, \& Jaksic (2017) confirmed in their research. They examined the impacts of chosen factors on the ROA profitability indicator.

Authors of this paper perceive Profit Margin and Total Assets Turnover as suitable indicators for the presented research. They are similar to the ROA and ROS indicators (for more see methodology). Total Assets Turnover calculates the ratio of Sales and Total Assets. Profit from ROA ratio is replaced by Sales. The ratio of EBIT and Sales (Profit Margin) can be considered as a ROS ratio. The productivity of the labour force is in this article substituted due to the accessibility of data by indicator Efficiency of Cost of Employees that measures financial effects of production against the cost of employees.

Gschwandtner \& Hirsch (2018) focused directly on the company's profitability. They describe a comparison of the US and EU food processing industry in their article. They found that the profit in the food industry is lower compared to other sectors. They attribute this fact to a high degree of competitive pressure. However, the low profitability of the sector is relatively stable in the context of crises. They have identified as the main drivers of profitability a firms size and a financial risk in this sector. The reason is the ability of large companies to perform more advertising, have higher consumer reputation and to manage the administrative burdens and competitive pressures. Among the shortcomings of their paper, they report the omission of important intangible firm-specific resources such as R\&D activity, patents and reputation, to quantify the impact of family/insider ownership for the EU, due to data unavailability. Additionally, Zielinska-Chmielewska \& Smutka (2018) perceive the question of profitability of the food industry as very important due to factors such as introduction of modern production technology, compliance with procedures in food production, continuous process of improving quality standards of raw materials and due to large number of actors who are competing for customers in the defined food market. Their article mentioned that the Polish food processing sector will be facing a decrease in the cost of raw materials' prices, as well as ready-made meat products. The lowest level of food prices are identified in Poland among V4 countries, specifically for meat production, as discusses Cipiur (2017) and reports a price decline of other basic foodstuffs in Poland for the period of years 2012 - 2016. Conversely, Kostikov, Mareš, \& Procházková (2019) argues that direct comparison, specifically within the economic efficiency of production, is not providing relevant outcomes. Reasons for that perception authors see mainly in food production sectors' segmentation and differing consumer behaviour in respective countries. The above facts prove a high demand for proper financial management, where it is not possible to ignore the importance of the application of effective financial controlling in the company. For increasing company value, Chalastra, Kotapski, Kozubíková, \& Kozubík (2019) even specify the importance of human capital in the person of a continuously educating financial controller who is capable of selecting and processing relevant information. 
Petrů, Kramoliš, \& Stuchlík (2020) consider the accessibility of information services about safety or quality of products, respectively, as an opportunity to change consumers' behaviour and subsequently these information services can also be regarded as an influencing factor for the supply side of the market place. In addition, it has to be considered also the price sensitivity of demand for food among respective consumers segments (Syrovátka, 2011). EU policies for food quality are primarily focused on securing secure and quality food for inhabitants and it is also respecting needs for creating the best conditions for the food processing industry and involved businesses within EU member countries (European Commission, 2014). Beyond the foregoing, one more specific aspect of satisfying consumer needs and product prestige can be mentioned. The need of food producers to be voluntarily certified beyond what is required by law can be expected in countries where a greater tradition of dining and a deeper historical link with a certain commodity is expected, as Giacomarra, Galati, Crescimanno, \& Tinervia (2016) demonstrated in their research on a sample of Italian winemakers.

Suchanek \& Kralova (2016) examined the relationship between customer satisfaction and business performance. They used an EVA indicator that was constructed through a modular method using the ROE indicator as an EVA equity. Customer satisfaction was evaluated by factors such as customer expectation, image, perceived product value, perceived product quality, the customer's own general satisfaction and customer loyalty. Higher customer satisfaction in certain areas then negatively impacted on the company's profitability due to costs. These costs should be perceived within the profitability of the company, too. The costs incurred to meet customer needs are not necessarily efficiently used. It depends on whether and how companies obtain credible end-user satisfaction data.

Next research of Suchánek, Richter, \& Králová (2017) states that companies that do not conduct a customer satisfaction survey or do it improperly affect their profits. It is a mistake to believe unfounded that firm knows what a customer's need. Maciejewski (2018) argues that food consumption patterns within V4 countries are considered to be rather rigid. This fact is identified as a negative influencing factor for introducing innovations in the food processing industry. Additionally, Puska, Stevic, \& Sadic (2019) support directly the idea of sharing information between a business, a supplier and a customer to support business performance and competitiveness based on the results of their research. Sharing information is not so common in the context of competition Zabolotnyy \& Wasilewski (2019) took a comprehensive approach to the financial health of companies. They presented their research with the concept of financial sustainability measurement in the example of food companies from Northern Europe where they used fuzzy logic to quantify complex interrelations among various financial factors and classify companies according to the level of their financial sustainability. They utilized in evaluating the variables as liquidity, profitability, productivity, debt, interest coverage, market capitalization, operating efficiency and retained earnings. Their sub-indicator of value reacted economically correctly in their results when companies increased their profitability, market capitalization or productive efficiency. The question is how the results of this research can be used for small and medium enterprises looking for simple partial solutions. Complex and more sophisticated insights into the performance of businesses, taking into account many factors, are typically used by large corporations and government institutions to make decisions.

Chaddad \& Mondelli (2013) conducted research on businesses in the US food economy. They found strategic factors affecting business performance. Specifically, these are corporate (diversification, R\&D intensity, capital intensity and resource availability), business segment (size) and industry (barriers to entry) variables. Based on the results of the research they have proposed several recommendations for managers, scientists and government. Managers should invest more attention to strategically managing resources and activities within extant industries than the analysis of new industries for competitive struggle. Researchers should focus on business unit and corporate differences in their studies on the other hand. Their results also indicate that the anti-monopoly office should lower the level of market entry barriers set up to 
promote free competition. Grzega (2015) provides a study of changes within consumption in Poland after a period of socio-economic transformation by also researching foodstuff. He concludes in his research that the presence of increasing satisfaction of consumers in Poland is bound both with qualitative and quantitative changes in the consumption of food.

It could be deduced that food industry faces a series of changes that will impact customers, business performance, food quality or safety incidents and the question is, how they will be reflected specifically in the competitiveness of economically smaller business entities. Belas, Strnad, Gavurov, \& Cepel (2019) note that SMEs are very sensitive to the economic downturn but benefit from a high degree of flexibility and high adaptability to changed conditions compared to large companies because they can adapt more quickly to the market situation. This situation emphasizes the need to increase cost-effectiveness and efficiency to maintain competitiveness. The comparison of the Visegrad 4 member countries in our article will provide an interesting interconnection of knowledge for the aforementioned aspects.

\section{METHODOLOGY}

In this article, authors employ approaches for revealing effects of qualitative factors within they interaction with accessible microfinance data of businesses settled in Visegrad 4 member countries, active in specific food manufacturing industry branch with an emerging quality and safety alert notifications in the last ten years. It is intended to join together information on reported food safety and quality standards from EU RASSF Portal and secondary corporate financial data of food processing companies, which were gathered from the ORBIS database of Bureau van Dijk. The food processing businesses settled in the Visegrad 4 member countries were identified via EU NACE industry classification with a focus on businesses, which were active in the EU NACE industry 10.12 - Manufacturing and preserving of poultry meat in the period of years 2009 - 2017. In order to meet the need for creating homogenous groups of observed businesses, authors exclude from the sample entities without own production capacities, such as groups of producers. Despite the aforementioned fact authors assume normality of data due to a sampling procedure for identifying active food producers. Expectation about the constitution of homogenous groups of businesses in Visegrad 4 member countries can be supported e.g. by findings of Ivanova \& Cepel (2018), who consider economies of Visegrad 4 member countries as similar at a general level. Observed businesses within the EU NACE industry 10.12 with consolidated financial statements were also excluded from the sample to decrease distortion in observation of financial performance. Sample of entities is then sorted out according to their economic size and country of settlement in Visegrad 4 member countries. Classification of businesses' economic size in the sample is the following:

- large companies: annual operating revenue higher than 10 million EUR; total assets for a yearperiod higher than 20 million EUR; a number of employees higher than 150;

- medium-sized companies: annual operating revenue higher than 1 million EUR; total assets for a year-period higher 2 million EUR; a number of employees higher than 15;

- small companies - other observed entities.

Selected financial indicators for the respective business performance analysis are regarded as proxies of production quality factors as following. Production ability and success of placing products on the market for single business entities were measured by the activity indicator Total Assets Turnover (TAT).The profitability of observed businesses is measured by profit margin ratio (PM) using Earnings Before Interests and Taxes ratio to cope with different tax conditions and cost of capital among assessed size categories of businesses and different countries of settlement. The last observed indicator is measuring the efficiency of the cost of employees (ECE). The aforementioned indicators are enumerated for respective annual finance business data as following: 


$$
\begin{array}{ll}
\text { - } & \text { TAT }=\text { Sales / Total Assets, } \\
\text { - } & P M=E B I T / \text { Sales, } \\
\text { - } & E C E=\text { Sales / Cost of Employees. }
\end{array}
$$

The sample of food-producing businesses involved in the exploration analysis within industry branch 10.12 - Manufacturing and preserving of poultry meat counts the following volumes of businesses with unconsolidated financial statements (see Tab. 1).

Table 1

Sample volume regarding economic size categories of observed businesses in the year 2009 and 2017

\begin{tabular}{|c|c|c|c|c|c|c|c|c|}
\hline \multirow{2}{*}{\begin{tabular}{c} 
Country $\begin{array}{c}\text { Econor } \\
\text { Economic size }\end{array}$ \\
\cline { 2 - 10 }
\end{tabular}} & \multicolumn{3}{|c|}{2009} & \multicolumn{4}{c|}{2017} \\
\hline Small & Medium & Large & $\begin{array}{c}\% \text { total of } \\
\text { population }\end{array}$ & Small & Medium & $\begin{array}{c}\text { Large } \\
\text { population }\end{array}$ \\
\hline Hungary & - & 7 & 6 & $93 \%$ & - & 5 & 6 & $100 \%$ \\
\hline Poland & 5 & 22 & 39 & $94 \%$ & 1 & 29 & 42 & $91 \%$ \\
\hline Slovakia & - & 2 & 1 & $75 \%$ & - & 2 & 2 & $80 \%$ \\
\hline
\end{tabular}

Source: Own work using data of database Orbis of Bureau van Dijk.

There is employed the Simple Factorial Analysis of Variance (ANOVA) approach for revealing mixed effects within selected multiple categorical independent factors. Researched categorical factors' levels are considered as sources of variance within all aforementioned financial performance indicators (1), (2) and (3). Observed values of financial performance indicators according to respective categorical factors (denoted as $\mathrm{y}_{\mathrm{ii}}$ ) are treated according to the following general model (e.g. Meloun, 2012):

$$
y_{i j}=\mu_{\mathrm{i}}+\varepsilon_{i j}
$$

where $\mu_{i}$ is the isolated observation of financial performance indicator values reported within the sample of businesses, $\varepsilon_{i j}$ denotes an error term.

Isolated observations of financial performance indicator values $\mu_{i}$ are decomposed to a partial representing overall mean value based on all the levels of researched categorical factors and respective level of researched factor (denoted as $\alpha_{\mathrm{i}}$ ):

$$
\mu_{\mathrm{i}}=\mu+\alpha_{\mathrm{i}}
$$

Conducted analysis of variance is subsequently followed by an additional comparison of means within observed indicators using the Scheffé test and focusing on the factor country of companies' settlement. Scheffé test compares all the combinations of column mean values within observed indicators of business entities according to the country of settlement. The testing criterion is based on FisherSnedecor F-test using an adjusted $\mathrm{F}$ testing criterion value $\left(\mathrm{F}_{\mathrm{s}}\right)$ as following (e.g. Cohen, 2008):

$$
F_{x}=(k-1) F_{c r i t}\left(k-1, N_{\tau}-k\right) \text {, }
$$

where $N \tau$ refers to a total number of subjects from all combinations of groups and $k$ refers to the number of groups.

Selected researched categorical factors include the economic size of business entity, country of settlement and reporting year as a proxy variable (the year 2009 representing data of a world economic cycle downturn, the year 2017 representing data of world economic cycle upturn).

Consequently, there are constituted respective hypotheses to be tested:

- Hypothesis H1: Selected categorical factors explains the variability of dependent indicator Total Assets Turnover at the corporate level in Visegrad 4 member countries.

- Hypothesis H2: Selected categorical factors explains the variability of dependent indicator Profit Margin at the corporate level in Visegrad 4 member countries. 
- Hypothesis H3: Selected categorical factors explains the variability of dependent indicator Efficiency of Cost of Employees at the corporate level in Visegrad 4 member countries.

Software Statistica 13 was utilized for enumerating procedures.

\section{EMPIRICAL RESULTS AND DISCUSSION}

Development of production capabilities using indicators reported by Eurostat (2020), namely production value and turnover per employee among manufacturers of food and feed (EU NACE 10 category) settled in Visegrad 4 member countries can be seen in Fig. 1. Indicator of production value considers total sales and changes in stocks of finished products or work in progress and other operating income excluding subsidies within the whole industry branch EU NACE 10 - Manufacturing of food, based on surveys of member countries statistical offices. Food and feed manufacturers settled in Poland represent the highest production value interconnected with a growing trend among Visegrad 4 member countries in the whole observed time period of years 2008 - 2017. Manufacturers in Poland also gained the highest turnover per employee in the period after the year 2012 among Visegrad 4 member countries that indicates a growing financial efficiency of labour force usage in Poland in comparison with decreasing or stagnating labour force efficiency in other Visegrad 4 member countries after the year 2012. This observed development in Poland concerning to increasing efficiency of the workforce among food manufacturers is consistent with the finding of Marchuk \& Fabiianska (2017) or Zielinska-Chmielewska \& Smutka (2018), who point out at factors of effectiveness and efficiency for maintaining competitiveness and profitability of food processing companies both in EU member and candidate countries.

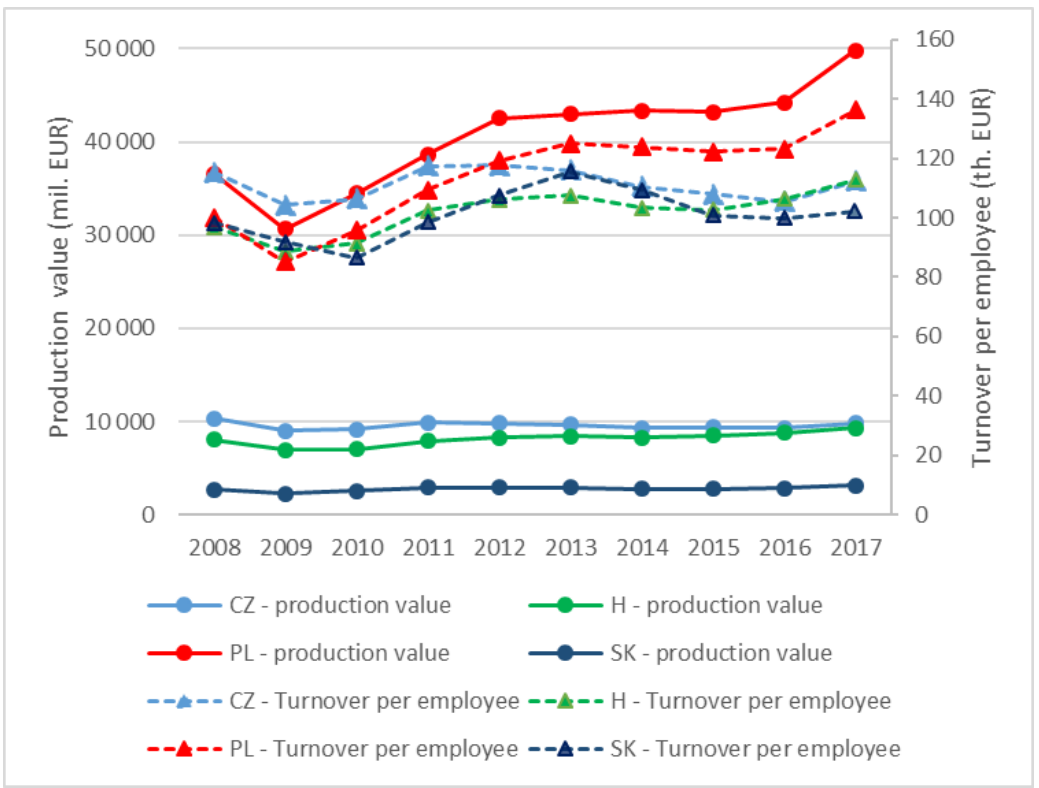

Figure 1. Development of production value and turnover per employee in industry EU NACE 10 among Visegrad 4 member countries in the time period of years 2008-2017

Source: Own work using data of Eurostat (2020).

Findings of the labour force efficiency are furtherly discussed via the development of total labour force and cost of employees among Visegrad 4 member countries (see Fig. 2). Despite a stagnation of a total number of employees in the time period of years 2008 - 2017 in all Visegrad 4 member countries, it can be seen the highest growing trend of personnel cost in Poland. In Poland, the observed personnel 
costs' development reached the level of the year 2008 again in the year 2012 and continued in growth. Volek et al. (2019) state that excessive growth in wages is negatively influencing the competitiveness of food producers. Conversely to this finding, positive development of total production value and also an ability to increase turnover per employee in Poland indicate growing labour productivity in comparison with rather a stagnation in all other Visegrad 4 member countries.

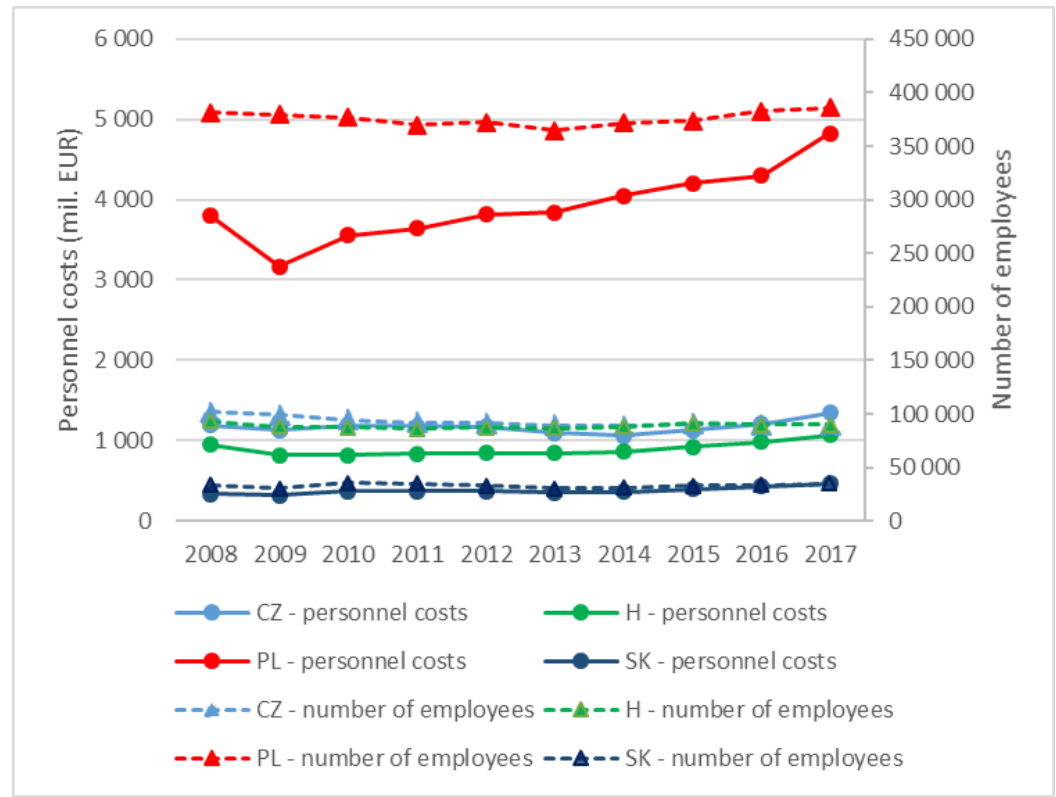

Figure 2. Development of personnel costs and number of employees in industry EU NACE 10 among Visegrad 4 member countries in the time period of years $2008-2017$

Source: Own work using data of Eurostat (2020).

Development of production factors efficiency but have to be closely interrelated with food and feed safety and quality aspects. Fig. 3 depicts the development of food safety and quality notifications with focus on poultry meat and poultry meat products industry branch in years 2009, 2017 and 2019. On the contrary, the accessible microfinance data for a sample of businesses are limited with the year 2017, so we point out at the emerging amount of food quality and safety incidents also in the year 2019. Food manufacturers in Poland are identified as business entities with the most cases of breaking food safety and quality standards within the industry branch manufacture of poultry meat and poultry meat products in the EU. As an alarming fact, it can be considered a growing trend within alert notifications that directly influences human health in the proportion of total food safety and quality notifications of EU RASSF. This negative development can be discussed in the scope of profitability goals anchored in the need for the sustainable competitiveness of food producers. As Suchanek \& Kralova (2016) state, the better meeting of customers' expectation about products' quality negatively influences the profitability of business entities. In addition to partial findings of increasing level of EU RASSF food safety and quality notifications in Poland, negative consumers' perception on quality of Polish products can be regarded as an influencing factor of profitability and competitiveness, respectively with consequent low price strategies as point out e.g. Richter (2016). Consequently, Thomas (2019) argues a dependence between the cost of food safety regulation and negative impact on wages of the operational workforce and this interrelation can be also regarded within deduction on target costing strategies of food with perceived lower quality from the consumers' side. 


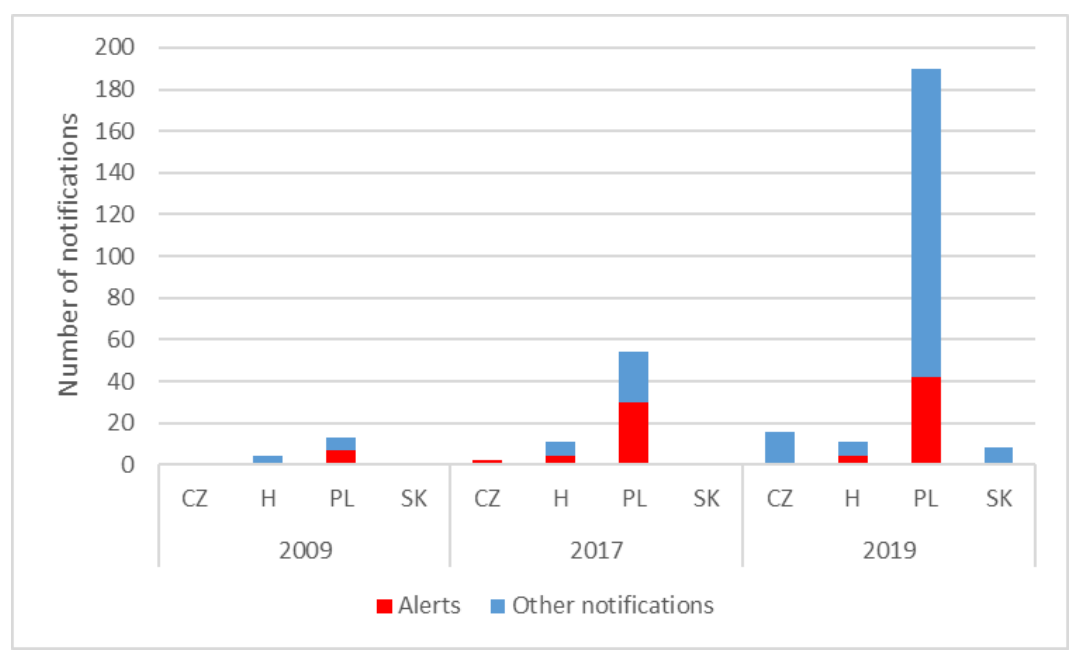

\section{Figure 3. Development of RASSF notifications on poultry meat and poultry meat products industry Visegrad 4 member countries and selected years \\ Source: Own work using data of RASSF portal (2020).}

Analysis of categorical influencing factors of selected industry branch poultry meat and poultry meat products (EU NACE 1012) is using financial performance indicators total assets turnover, profit margin and efficiency of cost of employees. Zabolotnyy \& Wasilewski (2019) consider the operating efficiency to be an influencing factor of financial health for the analysis of large companies. Due to a fact that food manufacturers enter the common EU market, authors consider the comparison of small, medium and large businesses as suitable by using the same set of financial ratios, namely indicators of activity, profitability and also efficiency. Comparable corporate financial data for all observed size categories manufacturers of poultry meat and poultry products settled in Visegrad 4 member countries are assessed by methods based on Factorial Analysis of Variance to identify common factors of the financial performance. Following findings for the period of years, 2009 and 2017 are revealed.

Verification of the hypothesis $\mathrm{H} 1$ that copes with proving of existence of common factors for observed variability of dependent indicator Total Assets Turnover at the corporate level in Visegrad 4 member countries is firstly providing outputs' visualisation of conducted factorial analysis of variance for three influencing categorical factors, namely country of settlement, time period and economic size. Interaction of all three aforementioned factors is not statistically significant. Despite this statistical insignificance, it can be stated that the highest mean value of total assets turnover was identified for both observed periods among medium-sized businesses, which were settled in Poland (see Fig. 4). 


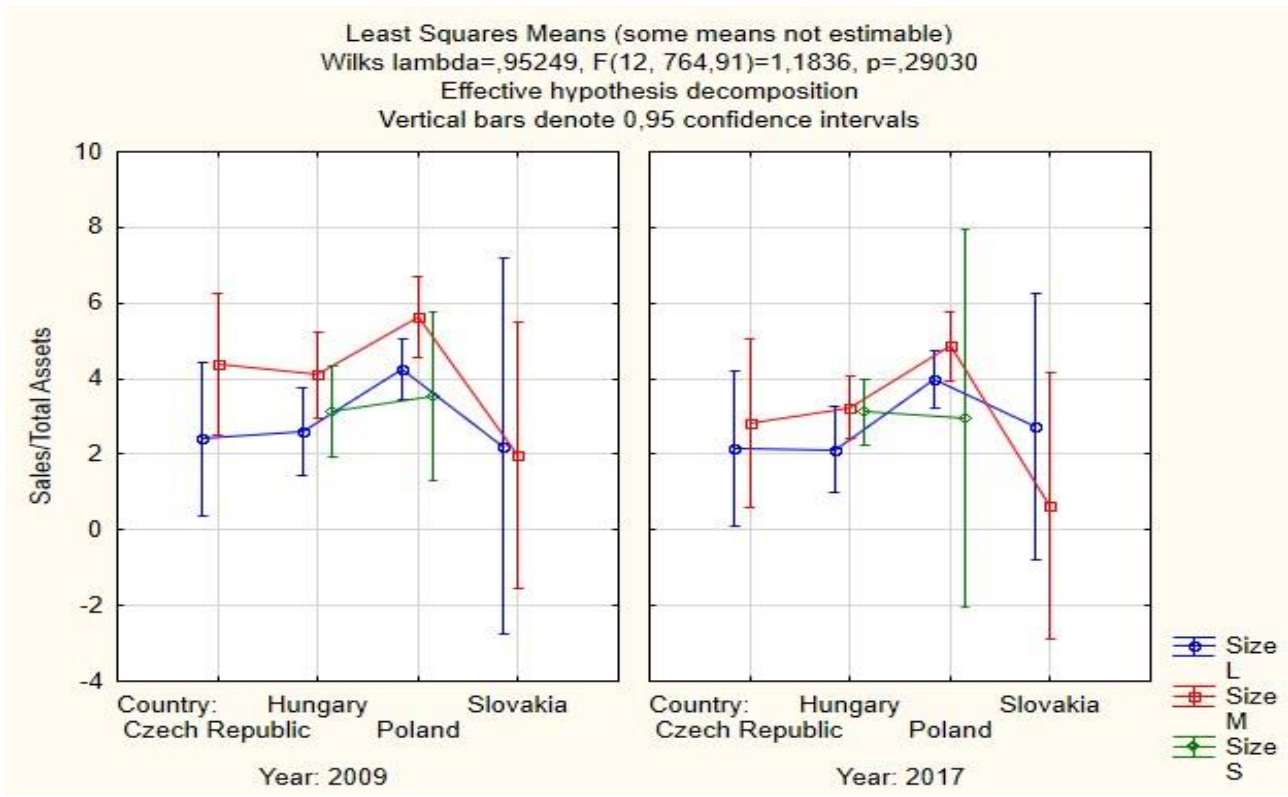

Figure 4. Comparison of indicator TAT for businesses active in industry EU NACE 1012 in observed years 2009 and 2017

Source: Authors' results.

Further partial decomposition of influencing factors revealed statistical insignificance of economic size to mean values of total assets turnover for this industry branch. It is a different finding in comparison with Gschwandtner \& Hirsch (2018), who state that economic size of businesses in the whole food manufacturing industry is one of the influencing factors of profitability when comparing EU and US food manufacturing industry, mainly due to the fact that this industry is facing a lower level of profitability. So, these authors stress also other influencing factors of better profitability of large companies, i. e. mainly better marketing communication. Conversely to the factor economic size of the business, it was identified a statistically significant difference in total assets turnover mean for the factor country of settlement in this article (see Tab. 2 and Fig. 5).

Table 2

Results of univariate tests for significance of influencing factors of indicator TAT for observed years 2009 and 2017

\begin{tabular}{|c|c|c|c|c|c|}
\hline \multirow[b]{2}{*}{ Effect } & \multicolumn{3}{|c|}{$\begin{array}{l}\text { Univariate Tests of Significance for Sales/Total } \\
\text { parametrization Effective hypothesis decomposition }\end{array}$} & $\left(1012 \_2009 \_2017\right)$ & Sigma-restricted \\
\hline & SS & $\begin{array}{l}\text { Degr. of } \\
\text { Freedom }\end{array}$ & MS & $\mathrm{F}$ & $\mathrm{p}$ \\
\hline Intercept & 763.322 & 1 & 763.323 & 117.273 & $<0.001$ \\
\hline \begin{tabular}{|l|} 
Country \\
\end{tabular} & 166.324 & 3 & 55.441 & 8.518 & $<0.001$ \\
\hline Year & 5.155 & 1 & 5.155 & 0.792 & 0.375 \\
\hline \begin{tabular}{|l|} 
Country* \\
Year
\end{tabular} & 2.484 & 3 & 0.828 & 0.127 & 0.944 \\
\hline Error & 1972.201 & 303 & 6.509 & - & - \\
\hline
\end{tabular}

Source: Authors' results. 
Fig. 5 provides a detailed insight into the analysis of indicator Total Assets Turnover regarding categorical factors country of settlement and period proxy, based on data of a sample of businesses. Mutual interaction of the factors mentioned above is not proved as statistically significant. Despite this fact, it can be stated that observed settled companies in Poland are those with the highest Total Assets Turnover both in the year 2009 and 2017.

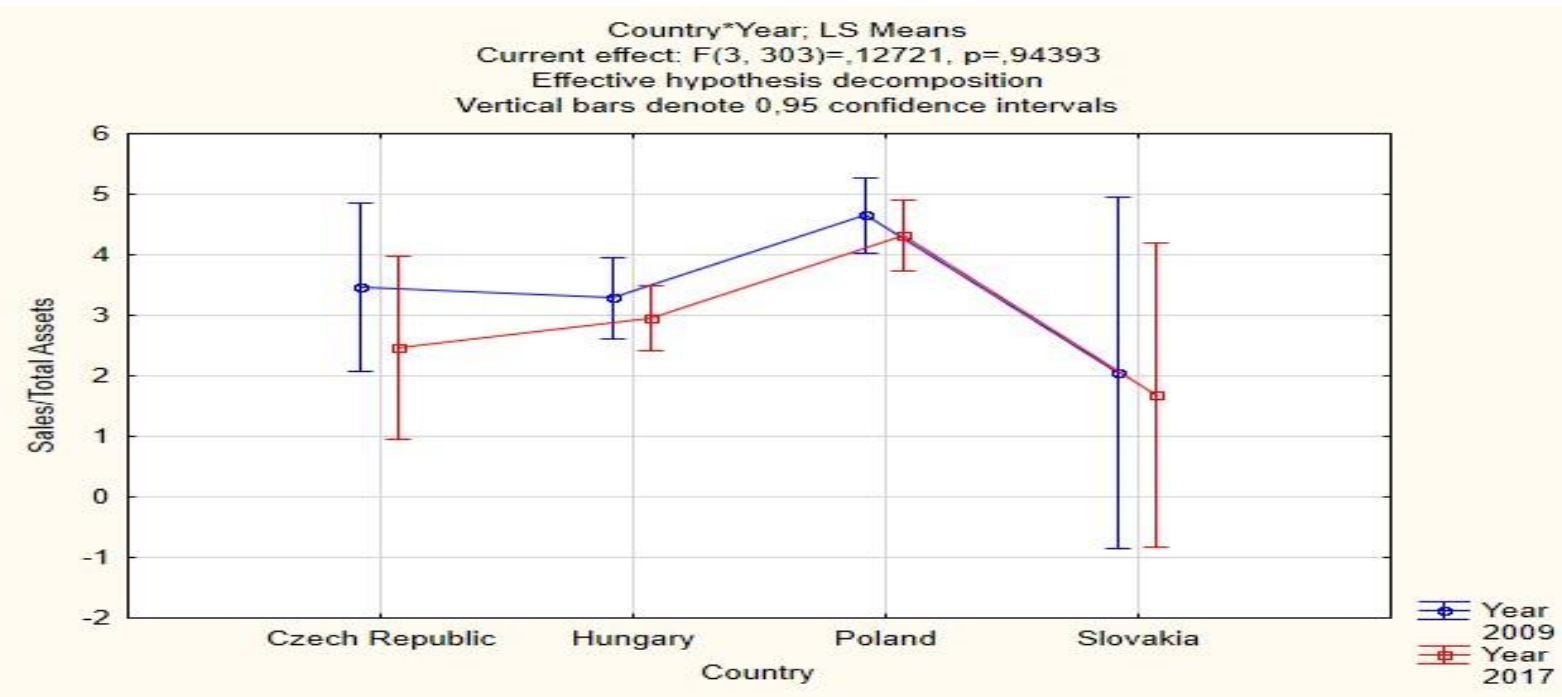

Figure 5. Decomposition of influencing factors of indicator TAT development for businesses active in industry EU NACE 1012 in observed years 2009 and 2017

Source: Authors' results.

Subsequently, it was conducted a post hoc comparison in order to test the mean differences among observed values of total assets turnover for the sample of businesses settled in Visegrad 4 member countries. Scheffe test for significant differences was employed. Results can be seen in Tab. 3. So, it could be partially concluded that manufacturers settled in Poland gained in both observed periods of years 2009 and 2017 significantly higher mean values of total assets turnover in comparison with other Visegrad 4 member countries at significance level 10 \%. According to findings of e. g. Marchuk \& Fabiianska (2017) investments to new production technologies are regarded to be a crucial factor in meeting food safety and quality standards. On the contrary, investments are decreasing total assets turnover in the short-run perspective.

Table 3

Results of Scheffe test for significant differences of observed means of indicator TAT among Visegrad 4 member countries

\begin{tabular}{|c|c|c|c|c|}
\hline \multirow[b]{3}{*}{$\begin{array}{l}\text { Cell } \\
\text { No. }\end{array}$} & \multicolumn{4}{|c|}{$\begin{array}{l}\text { Scheffe test; variable Sales/Total Assets (1012_2009_2017) Homogenous Groups, alpha }=.10 \text { Erro } \\
\text { Between MS }=6.509, \mathrm{df}=303\end{array}$} \\
\hline & \multirow[b]{2}{*}{ Country } & \multirow{2}{*}{$\begin{array}{c}\text { Sales/Total Assets } \\
\text { Mean }\end{array}$} & \multicolumn{2}{|c|}{ Homogenity Group } \\
\hline & & & 1 & 2 \\
\hline 4 & Slovakia & 1.838 & $* * * *$ & \\
\hline 1 & Czech Republic & 3.011 & $* * * *$ & \\
\hline 2 & Hungary & 3.078 & $* * * *$ & \\
\hline 3 & Poland & 4.476 & & $* * * *$ \\
\hline
\end{tabular}

Source: Authors' results. 
Verification of the hypothesis $\mathrm{H} 2$ that copes with proving the existence of common factors for observed variability of dependent indicator Profit Margin at corporate level in Visegrad 4 member countries is firstly providing outputs' visualisation of conducted factorial analysis of variance within indicator profit margin, employing the three influencing categorical factors country of settlement, time period and economic size can be seen in Fig. 6. Interaction of all three factors is not again statistically significant in this case. Despite this statistical insignificance, it can be stated that the highest mean value of profit margin was identified for middle-sized businesses settled in Slovakia in the year 2017. Santeramo et al. (2018) point out at need for investments in food processing companies due to changes in the regulation of areas such as global sustainability, protection of environment or food waste. So, these changes have to be reflected by innovation activities of food manufacturers with an expected negative influence on their profitability. Identified a low level of profitability in the food processing industry in this article can be discussed as a constraint in meeting this area of goals. Low level of profitability in the food manufacturing industry is also discussed e. g. by Gschwandtner \& Hirsch (2018).

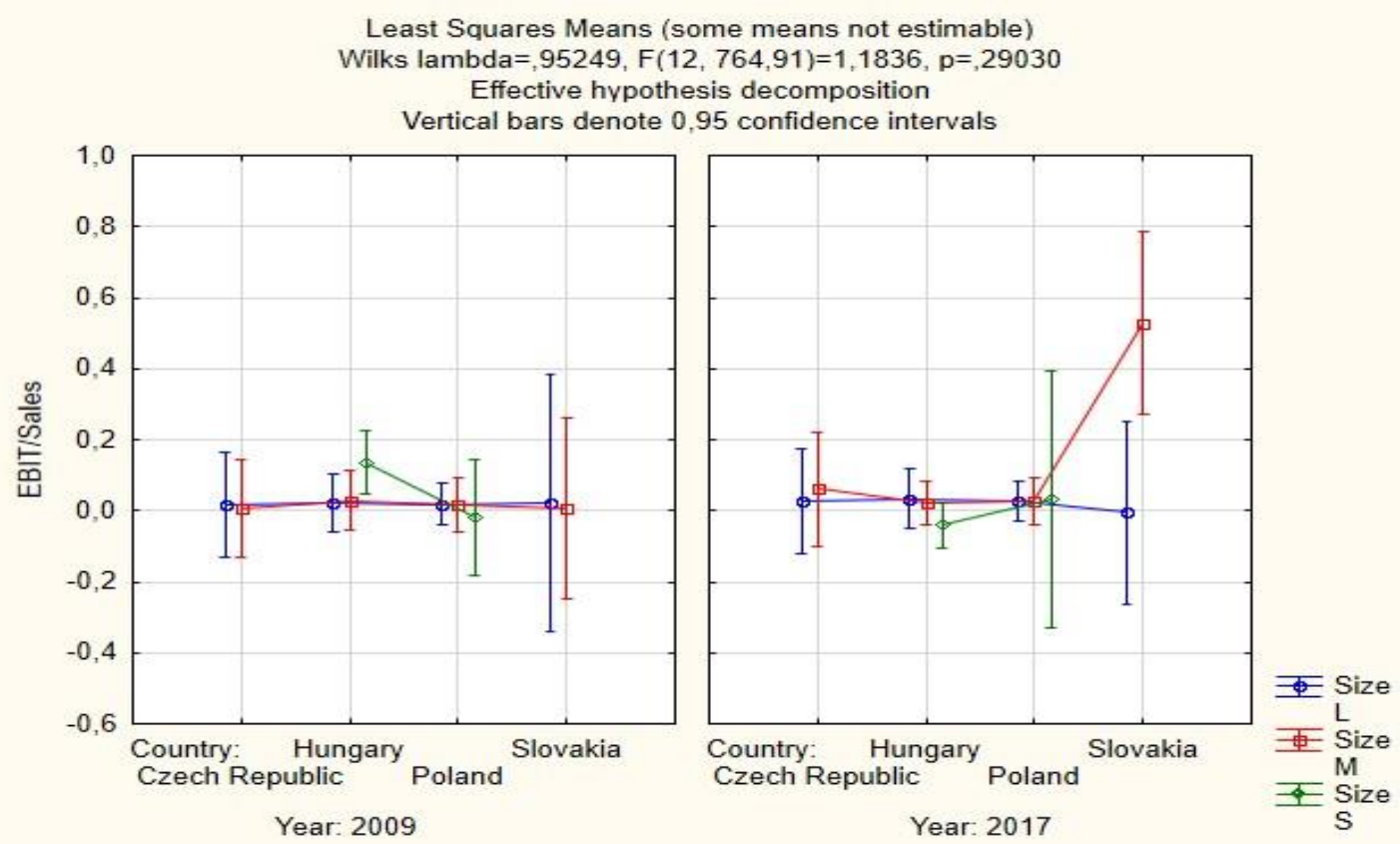

Figure 6. Comparison of indicator PM for businesses active in industry EU NACE 1012 in observed years 2009 and 2017

Source: Authors' results.

Further partial decomposition of influencing factors revealed statistical insignificance of interaction between categorical factors country of manufacturers' settlement and time period for the observed values of profit margin indicator at a significance level of $5 \%$.(see Tab. 4 and Fig. 7). Respective probability values (denoted as column "p") provides information to the reliability of the test, regarding the statistical significance of dissimilarities among respective observations. P-values provide information on the reliability of the conducted test, enumerated as the probability of correct assumption of hypothesis testing. P-values lower than $5 \%$ bring the probability of correct assumption of hypothesis testing higher than 95 $\%$ (i.e. 1 - p-value). 
Table 4

Results of univariate tests for significance of influencing factors of indicator PM for observed years 2009 and 2017

\begin{tabular}{|c|c|c|c|c|c|}
\hline \multirow[b]{2}{*}{ Effect } & \multicolumn{5}{|c|}{$\begin{array}{l}\text { Univariate Tests of Significance for EBIT/Sales (1012_2009_2017) Sigma-restricted parametrization } \\
\text { Effective hypothesis decomposition }\end{array}$} \\
\hline & SS & $\begin{array}{l}\text { Degr. of } \\
\text { Freedom }\end{array}$ & MS & $\mathrm{F}$ & $\mathrm{p}$ \\
\hline Intercept & 0.226 & 1 & 0.226 & 6.594 & 0.011 \\
\hline Country & 0.089 & 3 & 0.030 & 0.865 & 0.460 \\
\hline Year & 0.067 & 1 & 0.067 & 1.961 & 0.162 \\
\hline $\begin{array}{l}\text { Country* } \\
\text { Year }\end{array}$ & 0.219 & 3 & 0.073 & 2.132 & 0.096 \\
\hline Error & 10.374 & 303 & 0.034 & - & - \\
\hline
\end{tabular}

Source: Authors' results.

A detailed insight into the analysis of indicator Profit Margin regarding categorical factors country of settlement and time period proxy is provided at Fig. 7. Mutual interaction of the factors mentioned above is proved to be statistically significant, namely at a significance level of $10 \%$. So, it can be stated, that mean values of Profit Margin significantly differs in observed years and country of settlement. Namely, the highest Profit Margin was identified for businesses settled in Slovakia in the year 2017. Conversely, observed mean values of Profit Margins belongs to the lowest for both researched periods in the case of companies, which were settled in Poland.

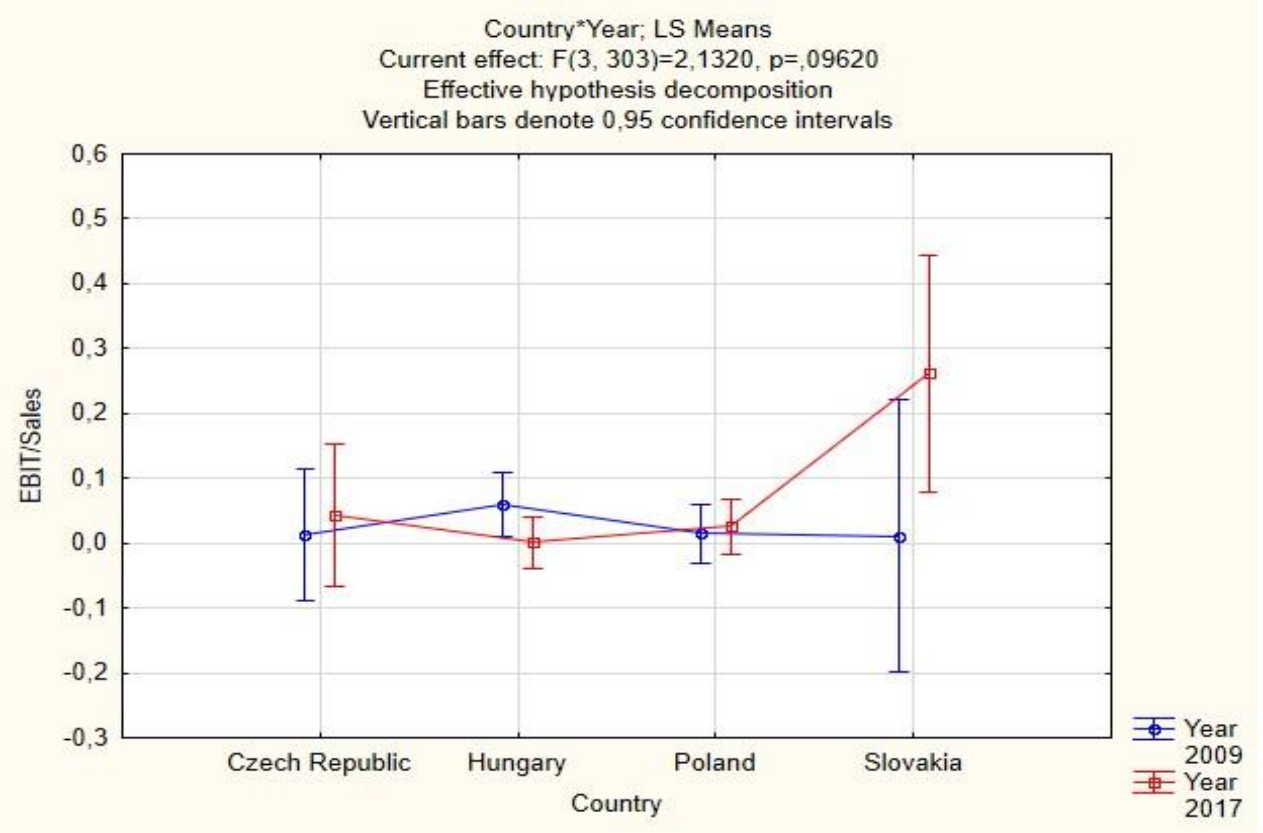

Figure 7. Decomposition of influencing factors of indicator PM development for businesses active in industry EU NACE 1012 in observed years 2009 and 2017

Source: Authors' results.

Statistical insignificance of differences between observed means of indicator profit margin for the sample of businesses was proved also by Scheffe test (see Tab. 5). So, it is concluded that there are no 
statistically significant differences in mean values of profit margin for the observed sample of manufacturers even at $10 \%$ significance level, pointing out at the broad confidence intervals of mean estimates in case of manufacturers settled in Slovakia in the year 2017. Long et al. (2018) point out the factor low level of profitability in the food manufacturing industry to be one of the barriers to the sustainability of producers in the long-run perspective. The aforementioned finding is based on the observation of small and medium-sized enterprises in the Netherlands.

Table 5

Results of Scheffe test for significant differences of observed means of indicator PM among observed countries

\begin{tabular}{|c|c|c|c|}
\hline \multirow{3}{*}{$\begin{array}{l}\text { Cell } \\
\text { No. }\end{array}$} & \multicolumn{3}{|c|}{$\begin{array}{l}\text { Scheffe test; variable EBIT/Sales (1012_2009_2017) Homogenous Groups, alpha }=.10 \text { Error: Between MS } \\
=.034, \mathrm{df}=303\end{array}$} \\
\hline & \multirow{2}{*}{ Country } & \multirow{2}{*}{$\begin{array}{c}\text { EBIT/Sales } \\
\text { Mean }\end{array}$} & Homogenity groups \\
\hline & & & 1 \\
\hline 3 & Poland & 0.021 & $* * * *$ \\
\hline 2 & Hungary & 0.024 & $* * * *$ \\
\hline 1 & Czech Republic & 0.026 & $* * * *$ \\
\hline 4 & Slovakia & 0.154 & $* * * *$ \\
\hline
\end{tabular}

Source: Authors' results.

Verification of the hypothesis H3 that copes with proving of existence of common factors for observed variability of dependent indicator Efficiency of Cost of Employees at corporate level in Visegrad 4 member countries (see Fig. 8) is firstly providing outputs' visualisation of conducted factorial analysis of variance for three influencing categorical factors (country of settlement, time period and economic size) in Visegrad 4 member countries. Mutual interaction of all three factors is not statistically significant. Despite this statistical insignificance, it can be stated that the highest mean value of the cost of employees' efficiency was identified for both observed periods of years 2009 and 2017 among manufacturers, which were settled in Poland.

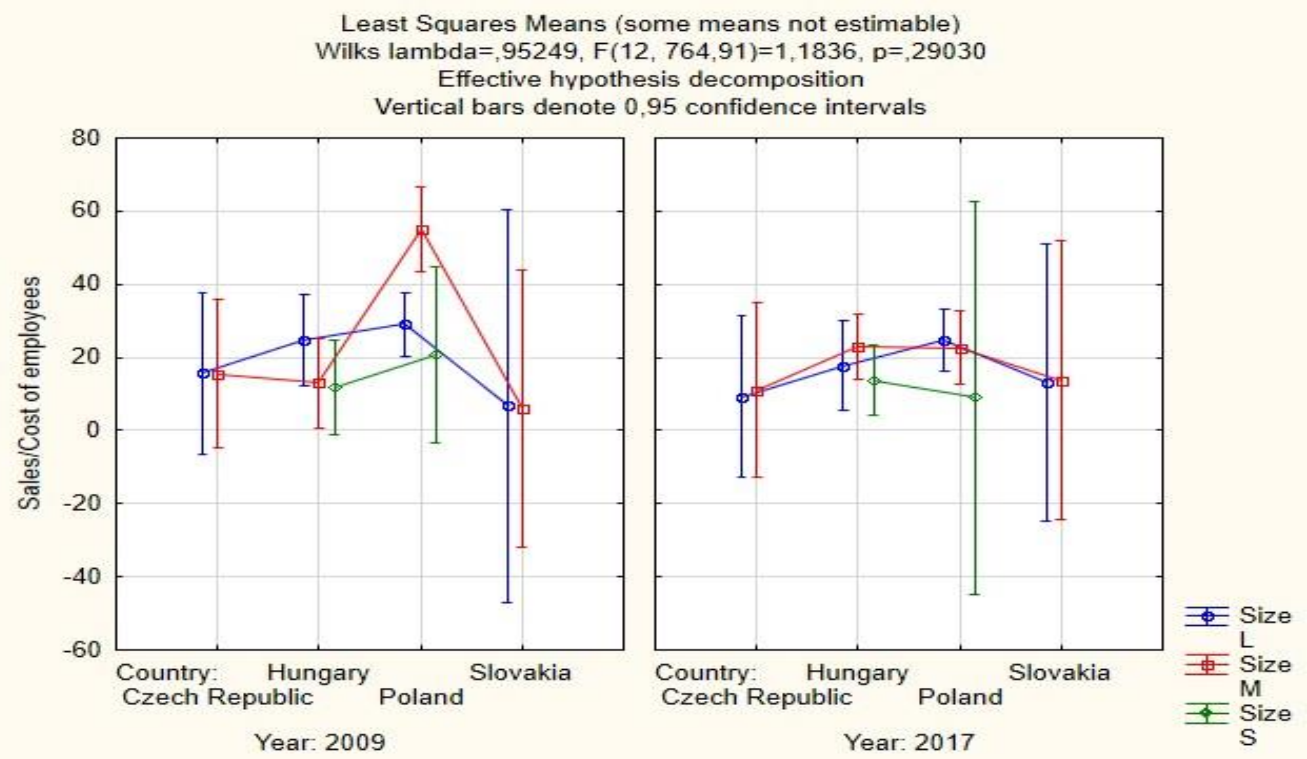

Figure 8. Comparison of indicator ECE for businesses active in industry EU NACE 1012 in observed years 2009 and 2017

Source: Authors' results. 
Further partial decomposition of influencing factors revealed statistical insignificance of economic size to mean values of the cost of employees' efficiency. Subsequently, it was identified a statistically significant difference in the cost of employees' efficiency mean for the factor country of settlement (see Tab. 6 and Fig. 9).

Table 6

Results of univariate tests for significance of influencing factors of indicator ECE for observed years 2009 and 2017

\begin{tabular}{|c|c|c|c|c|c|}
\hline \multirow[b]{2}{*}{ Effect } & \multicolumn{5}{|c|}{$\begin{array}{l}\text { Univariate Tests of Significance for Sales/Cost of employees (1012_2009_2017) Sigma-restricted } \\
\text { parametrization Effective hypothesis decomposition }\end{array}$} \\
\hline & SS & $\begin{array}{l}\text { Degr. of } \\
\text { Freedom }\end{array}$ & MS & $\mathrm{F}$ & $\mathrm{p}$ \\
\hline Intercept & 24661.2 & 1 & 24661.2 & 32.314 & $<0.001$ \\
\hline Country & 15170.3 & 3 & 5056.8 & 6.626 & $<0.001$ \\
\hline Year & 119.3 & 1 & 119.4 & 0.156 & 0.693 \\
\hline $\begin{array}{l}\text { Country*Y } \\
\text { ear }\end{array}$ & 4179.4 & 3 & 1393.1 & 1.825 & 0.142 \\
\hline Error & 231241.2 & 303 & 763.2 & - & - \\
\hline
\end{tabular}

Source: Authors' results.

Fig. 9 depicts the analysis output of indicator Efficiency of Cost of Employees regarding categorical factors country of settlement and period proxy. Mutual interaction of the factors above is not proved to be statistically significant. However, it can be stated, that observed mean values of the indicator Efficiency of Cost of Employees for observed businesses settled in Poland outperforms the companies from other V4 member countries both in the year 2009 and 2017.

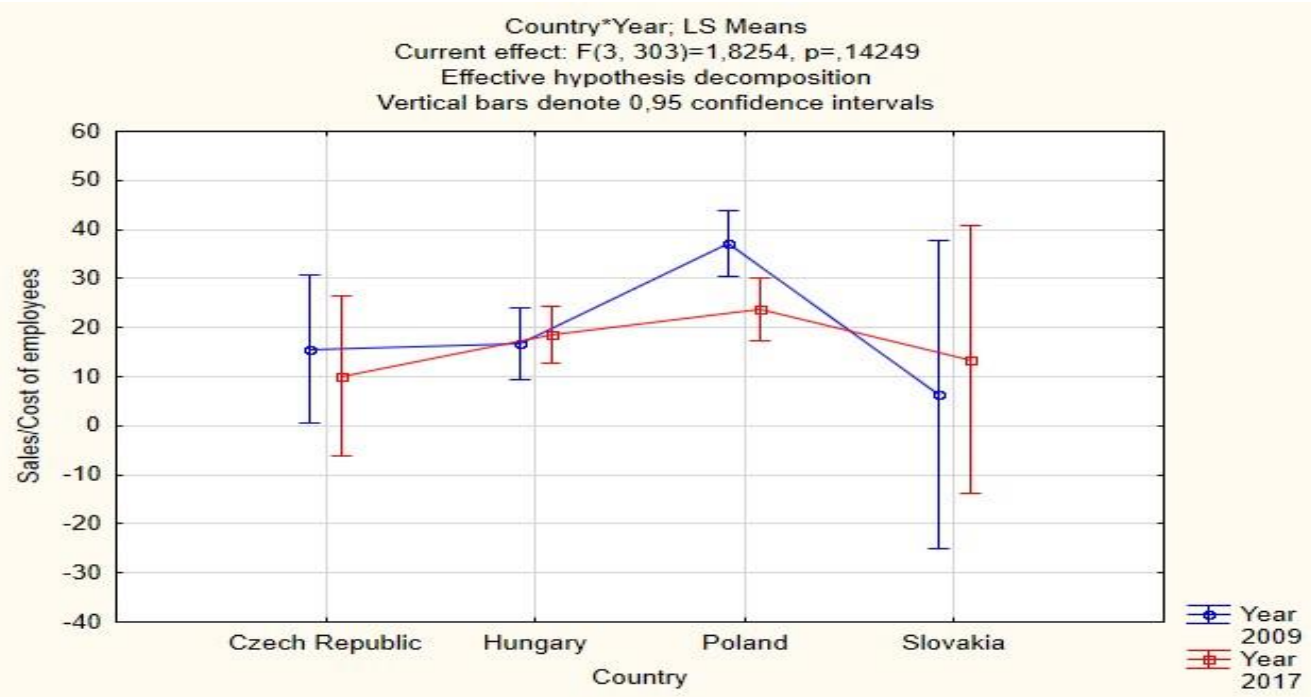

Figure 9. Comparison of indicator ECE for businesses active in industry EU NACE 1012 in observed years 2009 and 2017

Source: Authors' results.

A post hoc comparison for observed mean values of indicator efficiency of cost of employees revealed at $10 \%$ significance level that manufacturers settled in Poland had in the observed period 
significantly higher mean values of efficiency of cost of employees for the sample of businesses settled in Visegrad 4 member countries (see Tab. 7).

Table 7

Results of Scheffe test for significant differences of observed means of indicator PM among observed countries

\begin{tabular}{|c|c|c|c|c|}
\hline \multirow{4}{*}{$\begin{array}{c}\text { Cell } \\
\text { No. }\end{array}$} & \multicolumn{2}{|l|}{$\begin{array}{l}\text { Scheffe test; variable Sales/Cost of employees (1012_2009_2017) Homogenous Groups, alpha }=.10 \text { Error: } \\
\text { Between MS }=763.17, \mathrm{df}=30\end{array}$} & $\begin{array}{c}\text { Sales/Cost of employees } \\
\text { Mean }\end{array}$ & \multicolumn{2}{c|}{ Homogenity group } \\
\hline 4 & Country & 10.396 & $* * * *$ & 2 \\
\hline 1 & Slovakia & 13.055 & $* * * *$ & \\
\hline 2 & Czech Republic & 17.756 & $* * * *$ & \\
\hline 3 & Hungary & 30.108 & & $* * * *$ \\
\hline
\end{tabular}

Source: Authors' results.

A proven hypothesis $\mathrm{H} 3$ by the existence of a statistically significant categorical factor country of companies'settlement provides the partial result that indicator Efficiency of Cost of Employees is significantly higher for companies settled in Poland. Subsequently, this result is followed by the highest reported count of food safety and quality incidents among businesses settled in Poland. These outcomes are compared with the finding of Zielinska-Chmielewska \& Smutka (2018) that higher efficiency in labour force usage means a competitive advantage. Conversely, low level of wages can be an influencing factor of problems in meeting food safety and quality goals in respective food manufacturing businesses (e.g. Morano et al., 2018; Thomas, 2019).

\section{CONCLUSION}

Food safety and quality policy of the EU is regarded to provide one of the highest world standards in securing secure and quality food for consumers. Despite this fact, Rapid Alarm System for Food and Feed reports cases of placing dangerous products for human health on the EU common market. Poultry meat and poultry meat products industry belongs to a branch with an emerging amount of food quality and safety alerts, specifically in connection with production originated in respective CEEC countries in several last years. Aim of this article was to identify common factors of financial performance for businesses active in industry poultry meat and poultry meat products in Visegrad 4 member countries while considering the mutual interrelationship between the economic performance of food producers and quality of their products.

Review of a current state of the art using articles and studies of other authors point out at following factors within their influence on customer behaviour and preferences, namely the level of food literacy, product knowledge or purchasing power (Dudek, 2019; Erokhin, 2017; Ronto, Ball, Pendergast \& Harris, 2016; Savelli, Murmura, Liberatore, Casolani \& Bravi, 2019; Suchánek \& Králová, 2019). Companies respond to these factors by identification of changes in established consumer behaviour in order to maintain their competitiveness that can be measured among all by financial performance indicators. It could be generalized in the economic point of view that developing aspects of e. g. price sensitivity of consumers or their purchasing power has to be reflected by competitors.

Our research has taken advantage of a situation in the Visegrad 4 member countries, where overall economic growth is taking place, purchasing power and food literacy level is increasing, customer preferences are changing and food safety and quality problems with production placed on the common 
EU market still exists, even despite continuous adaptation process of legal regulation. A strategic perspective in the food manufacturing industry has to meet the goals of sustainability of food production and reduction of waste. Consumers' demand can influence the behaviour of food producers within the level of meeting food safety and quality standards or sustainability of production, respectively. So, selected financial performance indicators are regarded as proxies in meeting the aforementioned challenges and ability of food manufacturers to adopt them into their operational and strategic goals.

Testing of hypothesis on existence of common factors (i.e. economic size of businesses, period of economic downturn versus period of economic growth and country of settlement) for observed variability of selected financial indicators among sample of businesses settled in Visegrad 4 member countries, active in industry branch manufacture of poultry meat and poultry meat products revealed the following findings. It was proved the existence of a common factor for observed variability of dependent indicator Total Assets Turnover (hypothesis H1) within the sample of businesses, namely statistically significant difference in Total Assets Turnover mean for the factor country of settlement. This finding was subsequently furtherly tested for significance of mean values of the indicator Total Assets Turnover among Visegrad 4 member countries and it was proved a significantly higher Total Assets Turnover mean value for manufacturers settled in Poland. This finding points out at the highest production power of manufacturers settled in Poland among their competitors from other V4 member countries in the analysed industry branch. Medium-size businesses, despite statistical insignificance of mean values, are observed as those claiming higher Total Assets Turnover in comparison with other V4 member countries. An exception to this observation are businesses settled in Slovakia, with the highest Total Assets Turnover values for the sample of large businesses. It can be deduced that larger manufacturers have more intensive investment development that is mirrored in their activity indicator Total Assets' Turnover. The need for investment development is anchored both in the goals for labour productivity increase and meeting the given technological and hygienic standards of EU with their production capacities.

Testing for existence of common factors for observed variability of dependent indicator Profit Margin (hypothesis H2) did not prove the existence of any statistically significant common factor for observed variability of dependent indicator Profit Margin within the sample of businesses. This fact was also subsequently proved via non-significance of mean Profit Margin values differences among respective Visegrad 4 member countries. Observed values of profit margin are not significantly different in the period of the economic downturn (the year 2009) and economic growth (the year 2017). This fact points out on the one hand at the need for cost efficiency and on the other hand, at problems in the further development of this industry branch. Sustainable level of profitability is also discussed by other authors as a crucial factor of competitiveness.

Finally, it was proved the existence of a common factor for observed variability of dependent indicator Efficiency of Cost of Employees. Tests conducted according to hypothesis H3 identified statistically significant differences in observed values of the indicator Efficiency of Cost of Employees within the sample of businesses, namely statistically significant difference in mean values of this indicator for the factor country of settlement. Subsequently, it was proved that businesses settled in Poland gained higher efficiency of cost of employees in comparison with other Visegrad 4 member countries. This partial finding cannot be a separate claim of efficiency of labour force usage in Poland. A broader context has to be seen within wages' development in the manufacturing industry in Poland after the year 2012, i. e. increase of under-average wages in this industry. So, pressure on cost efficiency together with a missing willingness of consumers to appraise food safety and quality in the price of production creates a certain barrier for sustainable development and competitiveness of food manufacturers in CEEC countries. EU food safety and quality policy then create a legal framework for minimum required standards only. Higher 
qualitative levels of production can be constituted majorly by the free-market interrelationship between supply and demand.

Our current research was limited mainly by non-existence of detailed publicly accessible information on concrete producers, which were reported in EU Rapid Alert System for Food and Feed. The reason is to consider also non-financial factors in the area of food safety and quality, such as legal type of business entity, owner structure, production/technology certificates or fluctuation of employees. Interaction of financial and non-financial data for businesses breaking the food safety and security should be more helpful in complex identification of effects on policies and overall quality governance.

Authors consider the objective of the article as fulfilled by respective presented partial outputs of conducted analysis and their discussion with the current state of the art, based on the information resources in this problem area.

\section{ACKNOWLEDGEMENT}

This article was prepared as a partial output of project financed by Internal Grant Agency of FBE MENDELU in Brno, grant no. PEF_TP_2019004 "Aktuální trendy v oblasti kvality a bezpečnosti potravin a jejich vazba na finanční výkonnost tuzemských podniků potravinářského průmyslu”.

\section{REFERENCES}

Anderson, J. L., Asche, F., \& Garlock, T. (2019). Economics of Aquaculture Policy and Regulation. Annual Review of Resource Economics, 11(1), 101-123. https://doi.org/10.1146/annurev-resource-100518-093750

Belas, J., Strnad, Z., Gavurov, B., \& Cepel, M. (2019). Business Environment Quality Factors Research - SME Management's Platform. Polish Journal of Management Studies, 20, 64-77. https://doi.org/10.17512/pjms.2019.20.1.06

Cepel, M., Belas, J., Rozsa, Z., \& Strnad, Z. (2019). Selected economic factors of the quality of business environment. Journal of International Studies, 12(2), 228-240. https:/ / doi.org/10.14254/2071-8330.2019/12-2/14

Chaddad, F. R., \& Mondelli, M. P. (2013). Sources of Firm Performance Differences in the US Food Economy. Journal of Agricultural Economics, 64(2), 382-404. https://doi.org/10.1111/j.1477-9552.2012.00369.x

Chalastra, M., Kotapski, R., Kozubíková, Z., \& Kozubík, A. (2019). Human capital from the viewpoint of creating company value. Challenges for financial controllers. Management Sciences, 24(3), 3-9. https://doi.org/10.15611/ms.2019.3.01

Cipiur, J. (2017). Food in Poland is cheaper than in other European countries. Retrieved June 17, 2020, from https://www.obserwatorfinansowy.pl/in-english/food-in-poland-is-cheaper-than-in-other-europeancountries/

Cohen, B. H. (2008). Explaining Psychological Statistic. JohnWiley \& Sons.

Dudek, H. (2019). Food Insecurity in the V4 Countries: Microeconometric Analysis. Amfiteatru Economic, 21(51), 377-392. https://doi.org/10.24818/EA/2019/51/377

Erokhin, V. (2017). Factors Influencing Food Markets in Developing Countries: An Approach to Assess Sustainability of the Food Supply in Russia. Sustainability, 9. https://doi.org/10.3390/su9081313

European Commission. (2014). Food safety - Ensuring a high level of protection of human health and consumers' interests. Retrieved July 31, 2019, from http://europa.eu/pol/pdf/flipbook/en/food_en.pdf

Eurostat. (2020). Structural Business Statistics.

Giacomarra, M., Galati, A., Crescimanno, M., \& Tinervia, S. (2016). The integration of quality and safety concerns in the wine industry: the role of third-party voluntary certifications. Journal of Cleaner Production, 112, 267-274. https://doi.org/10.1016/j.jclepro.2015.09.026

Gómez, C., Currey, C. J., Dickson, R. W., Kim, H.-J., Hernández, R., Sabeh, N. C., ... Burnett, S. E. (2019). Controlled Environment Food Production for Urban Agriculture. HortScience, 54(9), 1448-1458. https://doi.org/10.21273/HORTSCI14073-19

Grzega, U. (2015). Changes in consumption in Poland in the period of transformation. Journal of International Studies, 
8(3), 152-163. https://doi.org/10.14254/2071-8330.2015/8-3/12

Gschwandtner, A., \& Hirsch, S. (2018). What Drives Firm Profitability? A Comparison of the US and EU Food Processing Industry. The Manchester School, 86(3), 390-416. https://doi.org/10.1111/manc.12201

Hron, J., \& Macák, T. (2010). Forecast of demand through the differential description of their effects. Agric. Econ., 56(4), 149-158. Retrieved from http://81.0.228.28/publicFiles/19062.pdf

Ivanova, E., \& Cepel, M. (2018). The Impact of Innovation Performance on the Competitiveness of the Visegrad 4 Countries. Journal of Competitiveness, 10(1), 54-72. https://doi.org/10.7441/joc.2018.01.0

Kostikov, E., Mareš, D., \& Procházková, R. (2019). Performance and stability of the sectors in the food industry of Czech Republic. Journal of International Studies, 12(3), 158-168. https://doi.org/10.14254/2071-8330.2019/12$3 / 13$

Long, T. B., Looijen, A., \& Blok, V. (2018). Critical success factors for the transition to business models for sustainability in the food and beverage industry in the Netherlands. Journal of Cleaner Production, 175, 82-95. https://doi.org/10.1016/j.jclepro.2017.11.067

Maciejewski, G. (2018). Food consumption in the Visegrad Group countries - towards a healthy diet model. The Central European Journal Of Social Sciences And Humanities, 361, 20-32. Retrieved from http://cejsh.icm.edu.pl/cejsh/element/bwmeta1.element.cejsh-1087dd5b-cbb7-419d-b159-f1ee8f3dde05

Marchuk, U., \& Fabiianska, V. (2017). Product quality as a condition for maximisation of profit: accounting and control aspects. Economic Annals-XXI, 163(1-2(1)), 85-90. https://doi.org/10.21003/ea.V163-18

Matošková, D., \& Gálik, J. (2009). Selected aspects of the internal and external competitiveness of Slovak agricultural and food products. Agric.Econ, 55(2), $84 \quad$ - $93 . \quad$ Retrieved from http://www.agriculturejournals.cz/publicFiles/04264.pdf

Meloun, M. (2012). Kompendium statistického apracování dat. Praha: Karolinum.

Michalski, G. (2016). Full operating cycle influence on the food and beverages processing firms characteristics. Agricultural Economics (Zemédélská Ekonomika), 62(No. 2), 71-77. https://doi.org/10.17221/72/2015AGRICECON

Ministry of Agriculture of the Czech Republic. (2018). Rámcová pozice na Sdělení Komise Evropskému Parlamentu, Radě, Evropskému hospodářskému a sociálnímu výboru a výboru regionů Budoucnost potravinářství a zemědělství v programovém období 2020+ COM. Retrieved August 1, 2019, from http://eagri.cz/public/web/file/591368/III_vlastni_material_RP_k_budoucnosti_SZP_proPVEU_final.pdf

Morano, R. S., Barrichello, A., Jacomossi, R. R., \& D’Acosta-Rivera, J. R. (2018). Street food: factors influencing perception of product quality. RAUSP Management Journal, 53(4), 535-554. https://doi.org/10.1108/RAUSP06-2018-0032

Palát, M. (2014). The causes of migration initiation and reflections on related theories. In 17th International Colloquium on Regional sciences. Conference Proceedings. (pp. 708-714). Brno: Masaryk University Press. https://doi.org/10.5817/CZ.MUNI.P210-6840-2014-91

Petrů, N., Kramoliš, J., \& Stuchlík, P. (2020). Marketing Tools in the Era of Digitization and Their Use in Practice by Family and Other. E\&M Ekonomics and Management, 23(1), 197-212. https://doi.org/10.15240/tul/001/20201-014

Puska, A., Stevic, Z., \& Sadic, S. (2019). Impact of Sharing Information with Supplier and Buyer on the Organizational Performance of Food Companies in Bosnia and Herzegovina. Economy and Market Communication Review, 9(1), 33-52. https://doi.org/10.7251/EMC1901033P

RASSF portal. (2020). Rapid alert system for food and feed. Retrieved from https://webgate.ec.europa.eu/rasffwindow/portal.

Richter, J. (2016). Analysis of Quality and Performance Development of Food Businesses. Business Trends, 6(1), 3-11.

Ronto, R., Ball, L., Pendergast, D., \& Harris, N. D. (2016). Food Literacy at Secondary Schools in Australia. Journal of School Health, 86(11), 823-831. https://doi.org/10.1111/josh.12440

Santeramo, F. G., Carlucci, D., De Devitiis, B., Seccia, A., Stasi, A., Viscecchia, R., \& Nardone, G. (2018). Emerging trends in European food, diets and food industry. Food Research International, 104, 39-47. https://doi.org/10.1016/j.foodres.2017.10.039

Savelli, E., Murmura, F., Liberatore, L., Casolani, N., \& Bravi, L. (2019). Consumer attitude and behaviour towards 
food quality among the young ones: empirical evidences from a survey. Total Quality Management \& Business Excellence, 30(1-2), 169-183. https://doi.org/10.1080/14783363.2017.1300055

Suchanek, P., \& Kralova, M. (2016). Customer satisfaction and underperformance in the food industry. In 3rd International Multidisciplinary Scientific Conference on Social Sciences and Arts, SGEM 2016 (pp. 829-837). Albena.

Suchánek, P., \& Králová, M. (2019). Customer satisfaction, loyalty, knowledge and competitiveness in the food industry. Economic Research-Ekonomska Istrą̌ivanja, https://doi.org/10.1080/1331677X.2019.1627893

Suchánek, P., Richter, J., \& Králová, M. (2017). Customer Satisfaction with Quality of Products of Food Business. Prague Economic Papers, 26(1), 19-35. https://doi.org/10.18267/j.pep.595

Syrovátka, P. (2011). Effects of changes in the tax environment on the consumer demand for food. Agric. Econ., 57(7), 350 - 355. Retrieved from http://www.agriculturejournals.cz/publicFiles/44410.pdf

Thomas, D. W. (2019). Regressive effects of regulation. Public Choice, 180(1-2), 1-10. https://doi.org/10.1007/s11127-018-00634-8

Volek, T., Novotná, M., \& Zeman, R. (2019). Labour Productivity and Competitiveness of SMEs in Food Industry. In 17th International Scientific Conference on Hradec Economic Days (pp. 501-508). Hradec Kralove: University of Hradec Králové. https://doi.org/10.36689/uhk/hed/2019-02-051

Vukovic, B., Andric, M., \& Jaksic, D. (2017). The impact of working capital management on company's profitability: empirical evidence from Serbia. Custos e Agronegocio, 13(1), 333-349.

Zabolotnyy, S., \& Wasilewski, M. (2019). The Concept of Financial Sustainability Measurement: A Case of Food Companies from Northern Europe. Sustainability, 11(18). https://doi.org/10.3390/su11185139

Zielinska-Chmielewska, A., \& Smutka, L. (2018). The Measurement of Profitability Level of Chosen Food Processing Enterprises. The Case of Poland. In A. Tonkovic \& B. Crnkovic (Eds.), 7th International Scientific Symposium „Economy of eastern Croatia - vision and growth” (pp. 627-636). Osijek: Sveučilište Josipa Jurja Strossmayera u Osijeku Ekonomski fakultet u Osijeku. 